\title{
A new species of Apronius Stal (Stenopodainae: Reduviidae) from Peru',2
}

\author{
Jenaro Maldonado-Capriles ${ }^{s}$ and P. W. Lozada-Robles ${ }^{4}$
}

ABSTRACT

\begin{abstract}
Apronius planus, new species, is described from Peru and compared with the A. ocfonotatus species group. Important anatomical details are illustrated.
\end{abstract}

RESUMEN

Nuevo especie de Apronius del Perú

Se describe la nueva especie Apronius planus de un ejemplar del Perú. Ésta se compara con las especies del grupo A. octonotatus y algunas de sus características anafómicas se ilustran.

\section{DESCRIPTION AND DISCUSSION}

The new species described below was found among reduviid material collected by the junior author. The holotype is deposited in the National Museum of Natural History, Washington, D. C. Measurements are in milimeters.

Apronius planus Maldonado and Lozada, new species Plate I.-Fig. 2-5

Male-overall color stramineous, ornamented with brownish, head and thorax darker than hemelytra. Head ornamented with brown as follows: elongate $\mathrm{Y}$-shaped vitta from interocular sulcus to jugae, tapering broad area from interocular sulcus to base of neck, margins of postocular lobe, laterally, and eyes. Antenna: basal 3/4 of segment I reddish brown, apex dark brown; basal half of II stramineous, apical half darkening to brown toward apex; III brown; IV missing. Jugae pale brown, tylus from above dark brown. Pronotum: anterior lobe brown; posterior lobe brown laterally, a widening median line with abundant very small brown granulations; six yellowish prominent spots as follows: apex of anterior angles or projections, a granule before middle constriction, and the humeral angles. Legs: femora-basal half mostly stramineous; fore

1Manuscript submitted to Editorial Board 5 February 1991.

${ }^{2}$ Our thanks to Thomas J. Henry, from the National Museum of Natural History, Washington, D. C., who kindly reviewed the original manuscript.

${ }^{3}$ Ad Honorem Professor, Department of Plant Protection.

${ }^{4}$ Universidad Nacional San Marcos, Museo de Historia Natural, Casilla 14034, Lima 14, Perú. 


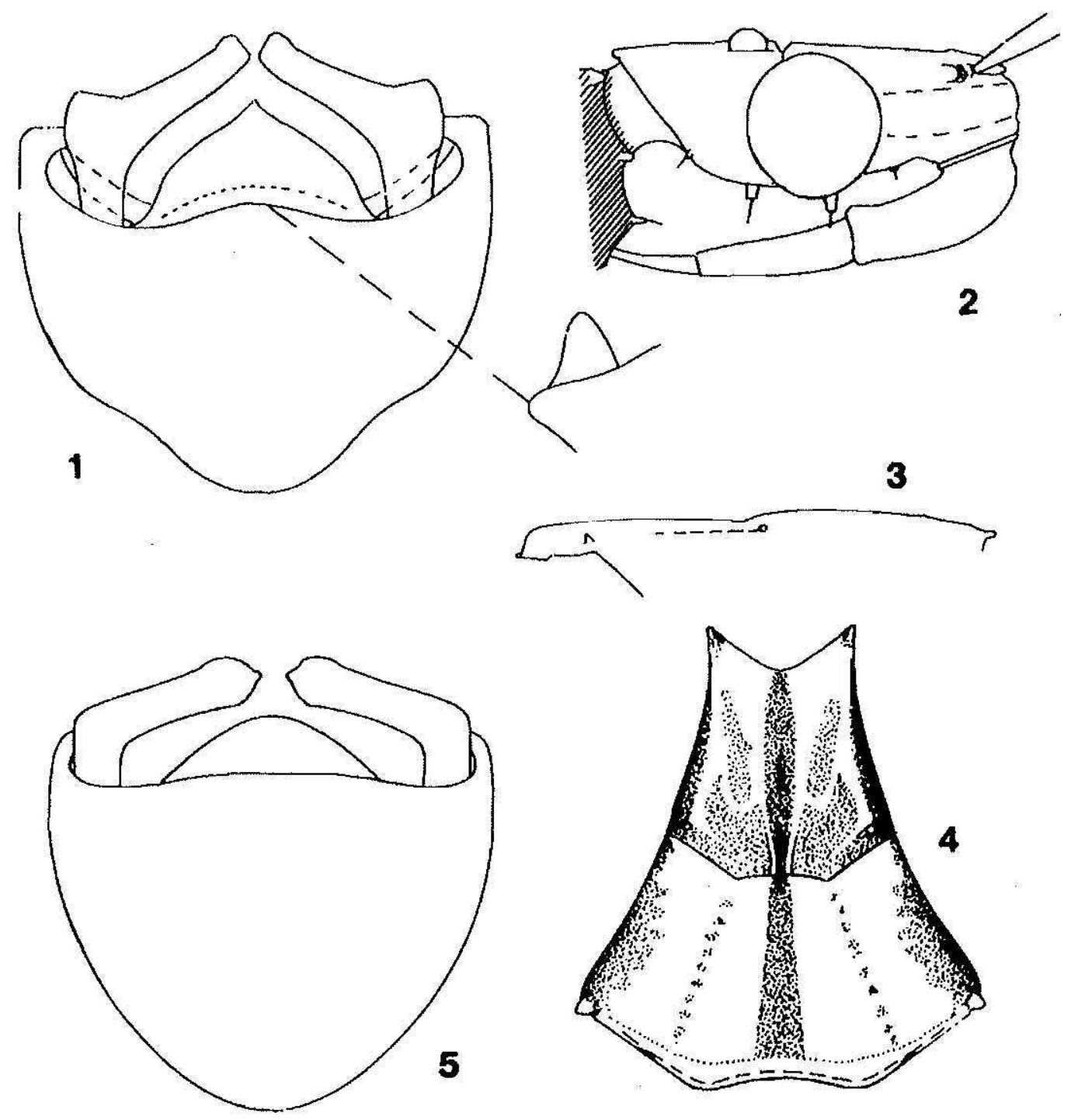

Plate I.-Apronius octonotatus Champion, male, fig. 1. genital capsule, caudal view. Apronius planus n. sp., male; fig. 2. head, lateral; fig. 3. upper surface of pronotum, anterior end to the right, lateral; fig. 4. pronotum, dorsal; fig. 5. genital capsule.

femur with a preapical brown annulus very close to extreme apex, irregularly and conspicuously spotted with stramineous; middle stramineous, annulus well separated from apex; hind with apical annulus. Fore tibia with three brown annuli; middle tibia with two brown annuli on apical half; hind tibia with 9-10 scattered brown spots, apex brown. Pronotum laterally and pleurae brown; metapleura with abundant yellow spots. Scutellum stramineous laterally, medially from base to apex of spine darkening from brown to dark brown. Hemelytra mostly stramineous, with small irregular brown maculations and spots; along costal margin, pterostigma and margin of membrane brownish, spotted with yellow; blackish spot as follows: inner corial cell caudad of scutellar apex, near 
inner angle of hexagonal discal cell, and discally on membranal cells; inner margin of clavus brownish. Abdomen: lateral margins of terga, connexivum above and below, and abdominal sterna variegated with brownish and fuscous, densely spotted with yellow.

Head: length including collum 2.4, width across eyes 1.6, interocular space 0.6 , collar 0.2, from apex of tylus to interocular sulcus 1.3. Antenna: I, 1.24; II, 2.1; III, 0.12; IV, missing; very short and moderately pilose. Lateral subantennal setigerous granule inconspicuous from above, on lateral view as in figure 2; setigerous spines on posterior lobe of head small, with very short setae; tylus sloping downward, below level of jugae; head ventrally with a pair of setigerous spines as follows: in front of projected anterior margin of eyes, below eyes, level with posterior margin of eyes, and ventrolaterally at base of head. Pronotum: anterior lobe-length 2.8, width 1.3, anterior angles sharply produced forward; granule before transverse suture small; discally with smooth and finely granulose areas (fig. 4); posterior lobe-moderately granulose, length 2.9 , width 2.8 to tip of humeral angles, angle ending in a sharp granule; in lateral view surface of both lobes at same level. Scutellum: basal width 0.85 , length 1.2. Fore leg: coxa with two anterior setigerous spines, trochanter with two ventral spines; femur 3.5 times thicker than tibia $(0.75: 0.2)$ and about twice as thick as middle femur (0.75:0.35); with a single row of thick spines that gradually diminish in size toward apex, area lateral to spines smooth to receive the tibia, followed by a straight row of setigerous spines enclosing the smooth area; tibia with a spongy fossa on apical fourth of segment, fossa slightly surpassing apex. Dimensions of legs: coxae $0.6,0.8,0.10$; femora $3.5,3.4,5.4$; tibiae $3.8,3.5,5.7$; tarsi 0.8. Caudal view of genital capsule as in figure 5 . Overall length of body $10.36 \mathrm{~mm}$, greatest width across abdomen $4.3 \mathrm{~mm}$.

Holotype male, PERU, PA, Prov. Oxapampa, San Juan de Cocacu, 20 IX 1987, $830 \mathrm{~mm}$., P. W. Lozada collector. A male paratype, probably from COLOMBIA, collector unknown, in the senior author's collection.

This new species belongs in a group with Apronius octonotatus since both have the surface of both lobes of the pronotum horizontal (hence the trivial name planus) (fig 3), in contrast to those in the other group in which the posterior is raised at an angle above the anterior lobe. It runs to couplet 2 with $A$. octonotatus in Maldonado's (1986) key. ${ }^{6}$ They differ as follows: $A$. planus-legs pale and mostly stramineous with conspicuous yellow spots, abdomen and connexivum brownish with small abundant and conspicuous yellow spots, and the genitalia (fig 5); $A$. octonotatus-legs, abdomen, and connexivum mostly brown and with few inconspicuous yellow spots, and the genitalia (fig 1).

\footnotetext{
${ }^{5}$ Maldonado-Capriles, J. 1986. Two new species of Apronius Stal with notes on the genus (Heteroptera: Reduviidae: Stenopodainae). J. N. Y. Entomol. Soc. 94(2): 174-79.
} 